\title{
Media dan Komodifikasi Dakwah
}

\author{
Yusron Saudi \\ Program Studi Komunikasi Penyiaran Islam, Fakultas Agama Islam \\ Universitas Muhammadiyah Mataram,83115, Indonesia \\ yusron.saudi@gmail.com
}

INFOARTIKEL

Riwayat Artikel:

DiterimaJuli 2018

Direvisi Agustus 2018

Disetujui September 2018
ABSTRAKSI

Abstrak: Islam pada dasarnya, bukanlah agama yang hanya tertuang dalam simbol tekstual dalam al-Quran dan Hadist semata. Islam sejatinya adalah agama yang tidak bisa menafikan gejala historis, sosial, budaya, politik, dan seterusnya. Dengan jumlah penganut yang tidak sedikit, serta tersebar diberbagai belahan dunia, termasuk Indonesia, Islam pun menjelma menjadi semacam "gejala pasar". Sebagai konsekuensi dari "gejala pasar", maka Islam pun mengalami proses komodifikasi. Dakwah sebagai bagian dari ajaran agama, juga tidak bisa mengelak dari komodifikasi, terutama semenjak lahirnya berbagai macam media informasi, termasuk media massa. Banyaknya program-program dakwah di media massa di satu sisi menambah transformasi nilai-nilai Islam, tapi di sisi lain terkadang merusak citra Islam, karena dakwah sebagai bagian suci dari ajaran agama, terkadang menjadi alat bagi media untuk meraih keuntungan dari keberadaan penduduk Indonesia yang mayoritas beragama Islam tadi. Tulisan ini berusaha untuk melacak jejak lahir komodifikasi, serta penggerogotannya pada ruang agama dan praktik dakwah, sampai pada akhirnya berusaha mencari titik temu antara komodifikasi dan dakwah.

Abstract:Islam basically is not a religion contained with textual symbols in the Koran and the Hadith only. Islam actually is a religion what cannot deny by historical, social, cultural, political, and so on. The number of adherents of Islam is never calculated as a small, because Islam is spreaded in various parts of the world, including Indonesia, Islam has become a kind of "market phenomenon". As a consequence of "symptoms of market", Islam also undergoes a commodification process. Da'wah as part of religious teachings also cannot avoid by commodification, especially since the birth of various information media, including mass media. The number of da'wah programs on the mass media is the one hand adds to the transformation of Islamic values, but on the other hand it sometimes damages the image of Islam, because da'wah as a sacred part of religious toughts. Which sometimes becomes a tool for the media to achieve the majority of Indonesia's population was a Muslim. This research seeks the traces of commodification, as well as its encroachment on the religious space and the practice of da'wah, until finally trying to find common ground between commodification and da'wah it self.

\section{Pendahuluan}

Mayoritas masyarakat abad ke-21 terutama di belahan Barat dan sebagian di belahan Timur, telah larut hidup yang serba instan. Munculnya budaya konsumtif tanpa disadari telah mengubah manusia itu sendiri sebagai komoditas sosial. ${ }^{1}$ Dalam masyarakat yang berorientasi pasar atau 
masyarakat konsumsi, umumnya memiliki cara pandang yang berbeda terhadap dunia, termasuk juga agama. ${ }^{2}$

Dalam masyarakat konsumsi, agama bukan sekedar sumber nilai dalam pembentukan gaya hidup yang agamis, melainkan lebih kepada instrument bagi gaya hidup itu sendiri. Agama kemudian tidak lebih berperan sebagai sebuah simbol untuk melakukan identifikasi terhadap seseorang atau sekelompok orang. Sehingga agama pun menjelma menjadi modal bagi media untuk mencari status dan keuntungan semata. ${ }^{3}$ Pada akhirnya, agama telah diperlakukan seperti halnya barang-barang yang telah diambil-alih oleh pasar untuk dikelola sedemikian rupa sehingga memiliki nilai jual. ${ }^{4}$

Sebagai bagian dari Islam, dakwahpun tak luput dari komodifikasi. Salah satunya adalah dengan menjadikan simbol-simbol agama sebagai mesin uang oleh media massa. ${ }^{5}$ Dakwah tak lagi dijadikan sebagai alat transformasi nilai Islam semata, tetapi dakwahpun dikemas sedemikian rupa sehingga mampu melahirkan keuntungan secara komersil bagi media itu sendiri.

Dalam konteks ini, harus dibangun semacam pemikiran yang kritis agar dakwah tidak keluar dari jalur yang sebenarnya. Harus dilakukan semacam evaluasi, terutama pada tataran sejauh mana para pelaku dakwah (da'i-da'i) mampu mengemban amanah dakwah. Harapannya, tidak muncul kesan bahwa dakwah hanya sebatas barang komoditas yang hanya memberikan keuntungan bagi produsen semata, tetapi malah mengabaikan dan melupakan tanggung jawab moral yang sebenarnya.

Berdasarkan fenomena di atas, dalam tulisan ini, penulis ingin mengupas beberapa masalah yang merujuk pada: a) Komodifikasi \& Kemunculannya, b) Komodifikasi Agama c) Fenomena Komodifikasi Dakwah c) Mencari Titik Kompromi antara Komodifikasi dengan Dakwah.

\section{Pembahasan}

\section{A. Komodifikasi dan Kemunculannya}

Berdasarkan Kamus Besar Bahasa Indonesia (KBBI), komodifikasi memiliki arti pengubahan sesuatu menjadi komoditas (barang dagangan) yang dapat diperjual belikan. ${ }^{6}$ Komodifikasi dapat diartikan sebagai segala sesuatu yang berkaitan dengan barang dagangan atau dengan kata lain merubah sesuatu yang bernilai guna menjadi nilai tukar (uang).

Komodifikasi pada dasarnya adalah anak cucu dari praktek Kapitalisme yang prinsip dasarnya adalah memproduksi sesuatu yang memiliki nilai tukar bukan nilai guna. Secara lengkap, Marx mendefenisikan kapitalisme sebagai suatu sistem ekonomi yang memberikan ruang kepada individu untuk menguasai sumber daya produksi vital yang digunakan untuk meraih keuntungan maksimal. ${ }^{7}$ Pandangan ini kemudian secara umum menyimpulkan bahwa fenomena kapitalisme berakar pada uang, dan secara khusus bagaimana mengelola produksi, distribusi dan konsumsi berlangsung.

Munculnya kasus komodifikasi dalam konteks Barat, sebenarnya tidak bisa lepas dari melebarnya sayap-sayap kapitalisme yang memang sedang tumbuh subur di Barat waktu itu.

\footnotetext{
${ }^{2}$ Yovantra Arief, Komoditas Syariah di Layar Kaca, dalam Yovantra Arief \& Wisnu Prasetyo Utomo, Orde Media: Kajian Televisi dan Media di Indonesia, (Yogyakarta: INSISTPress, 2015), h. 138

${ }^{3}$ Acep Iwan Saidi, Ramadan, Citra Spiritual, dan Tuhan dalam Televisi, dalam Yovantra Arief \& Wisnu Prasetyo Utomo, Orde Media: Kajian Televisi dan Media di Indonesia, (Yogyakarta: INSIST Press, 2015), h. 156

${ }^{4}$ Moch. Fakhruroji, Privatisasi Agama: Globalisasi dan Komodifikasi Agama, Komunika:Jurnal Dakwah dan Komunikasi Vol.8 No.1 Januari-Juni 2012.

${ }^{5}$ Menurut Yovanta Arief, Ketika sebuah tayangan, apapun itu, termasuk dakwah, jika hanya menjadi komoditas yang diakumulasi untuk keuntungan, maka logika internal dalam tayangan tersebut pun tak jauh dari logika akumulasi. Lihat, Yovantra Arief, Komoditas..., h.138

${ }^{6}$ Kamus Besar Bahasa Indonesia (KBBI).

${ }^{7}$ Stephen K. Sanderson, Makro Sosiologi, Sebuah PendekatanTerhadap Reaitas Sosial (terjemahan), (Jakarta: Raja Grafindo Persada, 2003), h. 160.
} 
Adanya prinsip meraih keuntungan yang sebesar-besarnya dari para pemilik modal (produser) harus dibarengi pula dengan banyaknya barang yang bisa diproduksi. Merekapun mulai memutar otak, kira-kira apa yang bisa diproduksi selain hal-hal di luar ekonomi yang awalnya tidak memiliki nilai jual, tetapi memiliki nilai guna. Akhirnya sampailah mereka (produser) pada kesimpulan bahwa budaya yang ada pada masyarakatpun bisa dijadikan barang komoditas, asalkan dikemas sedemikian rupa sehingga mampu mendatangkan profit.

Akhirnya, muncullah upaya-upaya pemadatan kultural. Budaya yang tadinya dianggap sebagai fenomena yang lumrah dan alamiah, kini berububah menjadi ladang rizki bagi kapitalis. ${ }^{8}$ Praktik komodifikasi pun akhirnya tidak dapat dihindarkan, yakni terjadinya proses produksi komoditas yang tidak hanya berlaku pada tataran ekonomi, tetapi mengacu kepada pengorganisasian dan konseptualisasi produksi, distribusi, dan konsumsi komoditas. Artinya, segala sesuatu yang memiliki nilai jual, maka bisa diproduksi dengan dalih mendapatkan profit tadi.

Di zaman modern, hadirnya teknologi-teknologi komunikasi dan informasi mutakhir (televisi, radio dll), semakin memicu suburnya proses komodifikasi ini. Komodifikasi seperti memiliki sandaran guna menancapkan konsep profane-nya. Muncullah kemudian asumsi bahwa proses komodifikasi mengakar kuat pada media. Hal ini tiada lain, karena media hanya dapat dimiliki oleh pemilik modal kuat. ${ }^{9}$ Dengan kata lain butuh modal besar untuk mendirikan sebuah media. Sehingga bila kebutuhan modal terpenuhi, upaya pemulihan keuntungan akan dilakukan sebesarbesarnya. Pada akhirnya bukan hanya sesuatu yang sifatnya ekonomis yang menjadi lahan komoditas tersebut. Manusiapun yang pada dasarnya adalah pelaksana proses produksi, pada akhirnya ikut menjadi korban komodifikasi, tak terkecuali atribut-atribut yang ada pada manusia. itu sendiri, termasuk agama.

Azyumardi Azra dalam tulisannya yang dimuat pada Koran Republika, mengutip pendapat Greg Fealy, dalam artikel "Consuming Islam: Commodified Religion and Aspirational Pietism in Contemporary Indonesia", bahwa istilah komodifikasi berasal dari commodity, yang antara lain berarti benda "komersial" atau objek "perdagangan". Jadi, komodifikasi dalam kasus beragama, adalah usaha untuk melakukan komersialisasi agama, atau mengubah keimanan dan simbolsimbolnya menjadi komoditas yang dapat diperjual belikan untuk mendapatkan keuntungan. ${ }^{10}$

Islam, seperti agama-agama yang lainnya, bukanlah sekedar agama yang termuat dalam alQuran, hadist, dan kitab-kitab agama semata, tetapi sekaligus gejala historis, sosial, budaya, politi, yang memang melekat bersamanya. Dengan banyaknya pemeluk Islam secara populasi, Islam pun masuk dalam konsep"gejala pasar". Sebagai "gejala pasar", Islam pun pada akhirnya mengalami proses komodifikasi yang tidak terelakkan". ${ }^{11}$

Karl Marx, jauh-jauh hari sudah memperkirakan bahwa, industri yang kapitalis memandang manusia bukan hanya sebagai manusia, tetapi manusia adalah instrumen yang mendukung kerjakerja kapitalis. Sehingga para pekerja itu hakikatnya adalah bagian dari alat-alat produksi. Ketika kapitalis berorientasi untuk menghasilkan sebuah produk dan masyarakat mengkonsumsi produk itu, maka hakikatnya itu tidak terjadi secara natural, melainkan dirancang dan diskenario oleh para penguasa ekonomi (produser) tadi. ${ }^{12}$

Kapitalisme adalah sebuah sistem yang memproduksi komoditas-komoditas, dan secara natural penciptaan komoditas adalah inti dari praktek ideologi Kapitalisme. Kerangka kerja Kapitalisme memahami keinginan-keinginan dalam kerangka komoditatas-komoditas yang

\footnotetext{
${ }^{8}$ Lihat, Munandar Sulaiman, Ilmu Sosial Dasar: Teori dan Konsep Ilmu Sosial, (Bandung: PT Rfika Aditama, 2015), h. 72

${ }^{9}$ Roy Thaniago, Orde Media: Sebuah Pengantar dalam Yovantra Arief \& Wisnu Prasetyo Utomo, Orde Media: Kajian..., h. 7 +Azyumardi Azra, Komodifikasi Islam, Koran Republika Edisi 11 September 2008. Versi yang sama mengenai pembahasan terkait Komodifikasi Islam, juga bisa di akses pada website UIN Syarif Hidayatullah Jakarta (www. uinjkt. ac.id). ${ }^{11}$ Ibid.

${ }^{12}$ Dalam pandangan Karl Marx, sejarah manusia pada dasarnya adalah sejarah perjuangan manusia. Hubungan antara sumber daya material adalah sirkular. Pihak yang satu mengontrol pihak yang lain karena memiliki sumber daya lebih banyak dibandingkan pihak yang dikontrol tersebut.Sindung Haryanto, Spektrum Teori Sosial dari Klasik Hingga Modern,(Jakarta: Ar-Ruzz Media, 2012), h.40.
} 
diproduksi berkaitan dengan pribadi, organisasi, ataupun perusahaan. Komoditas tersebut senantiasa menjadi pendukung utama ide kapitalisme. Dalam logika Kapitalisme, sesuatu yang dianggap bernilai dan berharga, tidak lain adalah komoditas yang bisa diperdagangkan. Logika ini tidak hanya menyentuh benda-benda ekonomi saja, namun juga menyusup ke dalam relasi-relasi sosial kehidupan manusia. ${ }^{13}$

Barang yang sudah diproduksi akhirnya harus didistribusikan kepada konsumen. Nah pada tahap inilah terjadi semacam konstruksi pemikiran masyarakat terhadap barang yang sudah diproduksi tadi misalnya, melalui iklan, selebaran, brosur, film, dan media-media lainnya. Sehingga masyarakatpun merasa bergantung kepada produk tersebut, padahal secara logika, dia sebenarnya tidak terlalu bergantung pada produk tersebut. Suatu contoh misalnya, ketika sebuah produk kecantikan (taruhlah sabun pembersih wajah) selesai diproduksi, maka langkah selanjutnya adalah memikirkan bagaimana produk ini bisa didistribusikan, dan dianggap penting oleh konsumen. Maka mulailah para produser sabun tersebut membuat semacam skenario (membangun image konsumen) melalui iklan misalnya. Agar produknya terkesan "maknyos" digunakanlah jasa artis yang memang dasarnya cantik sebagai model. Masyarakat pun secara tidak langsung (terutama ibu-ibu) mulai berpikir untuk menggunakan dan membeli produk kecantikan tersebut, dengan harapan bisa cantik seperti artis yang menjadi model iklan produk bersangkutan, padahal pada dasarnya mereka tidak butuh produk itu. Namun dalam konteks ini, media dengan kekuatan positiningnya, mampu menempatkan dalam benak masyarakat tentang apa yang seharusnya dianggap penting dan tidak penting.

Karena merasakan hasil produksi yang semakin lama semakin mendatangkan keuntungan yang melimpah, akhirnya para industrialis kapitalis pun mulai memutar otak, apa yang bisa kami jual? Pada titik inilah akhirnya mereka melihat bahwa, agama (termasuk Islam) merupakan gejala pasar yang begitu menggiurkan, sehingga simbol-simbol agama pun dikemas sedemikian rupa, sehingga pada akhirnya, agama yang awalnya dianggap sakral (suci), dikomodifikasi menjadi sesuatu yang profan (memiliki nilai tukar). ${ }^{14}$ Komodifikasi pun akhirnya tidak lagi hanya berorientasi pada halhal yang sifatnya mundane (keduniaan semata), seperti contoh kasus sabun kecantikan di atas, tetapi mulai memasuki bidang-bidang yang sifatnya murni keagamaan.

\section{B. Komodifikasi Agama dan Kemunculannya}

Terjadinya komodifikasi agama pada dasarnya tidak bisa lepas dari keadaan agama itu sendiri di era globalisasi. Dalam jurnalnya yang berjudul "Privatisasi Agama: Globalisasi dan Komodifikasi Agama", Much Fahrurozi mengupas point of view para sosiolog Barat yang beranggapan bahwa agama di dunia Barat Modern (umumnya) sudah mengalami gejala privatisasi agama, terutama sejak tahun $1960 .{ }^{15}$ Pendapat ini secara umum, lahir dari adanya anggapan bahwa agama tak lebih dari sekedar ilusi dan hiburan sesaat bagi manusia untuk lari dari jeritanjeritan hidup, akan tetapi secara totalitas tidak pernah mampu menyelesaikan segudang permasalahan hidup itu tadi. Ini sepertinya menjadi titik tolak ketidakpercayaan sebagian orang terhadap peran agama dalam mengatur kehidupan sosial.

Benih-benih acuh tak acuh dalam beragama ini pada awalnya sudah lama menggeliat, terutama dalam diri para ilmuan-ilmuan besar, misalnya Nietzhe (1844: 1900) dengan ungkapan nyelenehnya mengatakan "Tuhan telah Mati” ${ }^{16}$ Agama pun dianggap lebih banyak menekankan

\footnotetext{
${ }^{13}$ Afif Fusalhan, Kavitalisme Media Dan Komodifikasi Agama: Pesan di Balik Cerita Sinetron Religi Pesantren Rock n Roll Season 3,

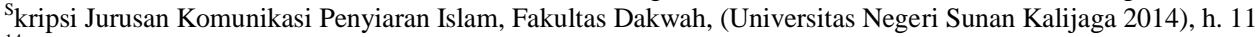

${ }^{14}$ Menurut Karl Marx, pada dasarnya setiap komoditas memiliki nilai guna komuditas, yakni ketika barang-barang yang diproduksi digunakan sendiri-sendiri atau digunakan orang lain untuk bertahan hidup. Tetapi dalam era kapitalisme, setiap komoditas yang sengaja dihasilkan untuk dijual ke pasar, produk-produk tersebut tidak hanya memiliki nilai guna, namun juga memiliki nilai tukar. Lihat, Rahma Sugihartati, Perkembangan Masyarakat Informasi \& Teori Sosial Kontemporer, (Jakarta: Kencana Prenada Mediaa Group, 2014), h. 19

${ }^{15}$ Moch. Fakhruroji, Privatisasi Agama...

${ }^{16}$ Komarudin Hidayat, Kegagalan Peran Sosial Agama”, Dalam Revitalisasi Islam, (Yogyakarta: Pustaka Pelajar, 2001), h. 25
} 
pada urusan individu daripada memberikan kontribusi bagi urusan publik. Pada titik inilah kemudian mereka (para sosiolog) menamainya fenomena tersebut dengan istilah "privatisasi". ${ }^{17}$

Irwan Abdullah sendiri memandang, bahwa privatisasi dalam beragama tidak lahir dari lubang batu, tetapi era globalisasi berperan besar dalam membentuk praktik kehidupan yang beragam, termasuk bagaimana orang beragama. Ia menekankan bahwa perubahan ini bukan disebabkan agama itu mengalami kontekstualisasi, tetapi lebih kepada budaya yang sudah mulai mengkontekstualisasikan agama sesuai kacamata global, dan dengan tata nilai yang berbeda pula. ${ }^{18}$

Dengan adanya pesimisme dan apatisme terhadap peran agama ini pun, pada akhirnya tokohtokoh agama mulai mengkaji dan menafsir ulang ajaran keagamaannnya. Mereka mulai lebih membuka diri denganmengaitkan persoalan dunia dan akhirat. Sehingga kesan agama adalah menara gading yang angkuh dan jauh dari hiruk pikuk manusia, kini menjadi lebih familiar dengan kehidupan sosial kemasyarakatan. ${ }^{19}$

\section{Fenomena Komodifikasi Dakwah}

Dalam proses komodifikasi, sesuatu diproduksi bukan atas dasar nilai guna, melainkan lebih kepada nilai tukar. Artinya sesuatu diproduksi bukan semata-mata memiliki kegunaan bagi khalayak, tetapi lebih karena sesuatu itu bisa dipertukarkan di pasaran. Dengan demikian, orientasi produksi bukan untuk memenuhi kebutuhan objektif masyarakat, tetapi lebih mendorong akumulasi modal. ${ }^{20}$

Dakwah yang juga merupakan bagian penting dari syi'ar Islam, dan awalnya dipandang sakral, kemudian mewarnai potret acara media massa di Indonesia. ${ }^{21}$ Televisi misalnya, telah mengubah dakwah tidak lebih sekedar hiburan. Para da'i yang mengisi tayangan dakwah tersebut dengan cepat menjadi idola dan figur baru di masyarakat. Mereka yang semula hanya dikenal dan berpengaruh di lingkungannya, tiba-tiba menjadi sedemikian terkenal di luar komunitas dan masyarakatnya karena memanfaatkan atau dimanfaatkan oleh para pengontrol teknologi informasi. Umat tidak hanya senang dengan gaya dan materi ceramah mereka, bahkan sampai ada yang meniru cara berpakaian, intonasi berbicara, dan ciri khas dari da'i yang diidolakan. Dengan alasan mengangkat citra agama, para da'I pun ada kalanya berprilaku dan bergaya hidup seperi selebritis, lekat dengan simbol-simbol kemewahan dan gaya hidup modern lainnya. ${ }^{22}$

Wajarlah jika kemudian Idi Subandi Ibrahim (Kompas, 27-08-2011), berujar, bahwa munculnya berbagai acara dakwah yang cair, sarat canda tawa sekaligus air mata, di berbagai media massa bukanlah sesuatu yang mengejutkan. Di mana kesadaran orang tentang hal-hal yang bersifat spiritual dipertemukan dengan kesadaran orang untuk mengkonsumsi tontonan. ${ }^{23}$ Media popular, terutama televisi dengan canggih memanfaatkan potensi artis, kiai pop, ulama pop, mubaligh pop, untuk melakukan "selebritisasi" pengalaman keagamaan mereka ke dalam paketpaket tontonan yang rutin, terutama pada momen-momen hari besar keagamaan. Hal ini lebih banyak kepada fenomena dagang saja. Karena tujuannya dagang, semua aspek dakwah harus disesuaikan dengan format acara hiburan.

\footnotetext{
${ }^{17}$ Ibid.

${ }^{18}$ Irwan Abdullah, Konstruksi dan Reproduksi Kebudayaan, (Yogyakarta: Pustaka Pelajar, 2007), h. 107

${ }^{19}$ Abdullah sattar, Komodifikasi Agama Dalam Televise, Jurnal Penelitian Vol. 18. No. 2. Tahun 2013.

${ }^{20}$ Fitri Murfianti, Komodifikasi Dakwah Dalam Religiotainment Di Stasiun Televisi Indonesia

Jurnal.ISI-Volume 3 no. 1 Juni 2012

${ }^{21}$ Jika di rujuk dalam beberapa ayat al-Qur'an, misalnya dalam (Q.S 16:125) dan (Q.S, 41:33) memperkuat bahwa Islam adalah agama "misi", yaitu agama yang harus disampaikan kepada manusia. Lihat, Acep Aripudin, Sosiologi Dakwah, (Bandung: PT Remaja Rosdakarya, 2013), h. 138.

${ }^{22}$ Ibid.

${ }^{23}$ Idi Subandi Ibrahim kemudian menamakan fenomena yang demikian dengan istilah "Religiotainment", yang merupakan gambaran adanya hiburan dengan sentuhan agama, atau agama dengan bumbu hiburan. Lihat, Idi Subandi Ibrahim, Budaya Populer sebagai komunikasi: Dinamika Popscape dan Mediascape di Indonesia Kontemporer, (Yogyakarta: Jalasutra, 2007), h. 155
} 
Jalaluddin Rakhmat pun tak jauh berbeda dengan Idi Subandi, ia menganalisis bahwa fenomena komodifikasi bak perpindahan ruang tabligh dari masjid dan majelis ta'lim ke pasar. Agama telah berubah dari hubungan sakral dengan Yang Mahakasih menjadi hubungan produsen dengan konsumen. Agama bukan lagi nilai-nilai agung yang mencerahkan secara ruhaniah. Agama hanyalah salah satu komoditas yang dijualbelikan di pasar kapitalis. ${ }^{24}$

Pada akhirnya, jika ingin ditarik sebuah pengakuan, tayangan dakwah di media massa (komodifikasi) memang membuat citra Islam lebih responsive terhadap dinamika zaman. Publik bisa mendapatkan informasi keagamaan atau mendapat jawaban mengenai persoalan yang dihadapi. Namun di sisi lain, komodifikasi dakwah menimbulkan keperihatinan tersendiri karena agama yang sakral hanya menjadi bumbu dan pemanis hal-hal yang profan. ${ }^{25}$ Semangat dan esensi agama pun lebur dalam hingar bingar industri hiburan, hingga esensi dakwahpun hilang ditelan oleh iklan.

Dari sisi substansi juga, kebanyakan para da'i terjebak dalam mengurusi ruang privat agama dan melupakan dimensi sosialnya. Umat diajak mencari pahala sebanyak-banyaknya melalui ibadah ritual, tetapi mengabaikan nasib umat-umat mereka yang masih terhimpit dalam kesulitan hidup. Ironi itu semakin mengiris luka hati, ketika para da'I selebritis tersebut dengan bangga memamerkan kemegahan rumah, harta kekayaan, seolah-olah mereka menutup mata dari derita yang dialami oleh umat. ${ }^{26}$

\section{Mencari Titik Kompromi antara Komodifikasi dengan Dakwah}

Komodifikasi Islam menjadikan Islam sebagai sebuah komoditas, apalagi komersialisasi Islam boleh jadi membuat banyak kalangan umat Islam mengerutkan dahinya. Apalagi, secara tradisional, banyak ulama menyatakan, agama tidak boleh dijadikan barang dagang untuk mendapat keuntungan dari penjualan dan perdagangan simbol-simbol agama. Bahkan, para ulama, ustadz, dan mubaligh diharapkan tidak mendapatkan nafkah apalagi profit material dari kegiatannya berdakwah. ${ }^{27}$

Tapi, apa boleh buat. Zaman sudah berubah dan komodifikasi Islam itu tidak bisa lagi dihindarkan. Mereka yang bergerak dalam bidang dakwah boleh jadi menolak istilah komodifikasi, dan sebaliknya mungkin lebih nyaman dengan istilah profesionalisasi. Profesional dalam dakwah, dan karena itu boleh saja berusaha mendapat profit dari profesi dakwah mereka.

Memang komodifikasi Islam tidak harus selalu berarti negatif, bahkan dalam segi-segi tertentu ada positifnya juga. Tetapi yang perlu diingat, sesungguhnya fenomena komodifikasi agama jika tidak disikapi dengan segera, bisa saja menjadi batu sandungan aktivitas dakwah itu sendiri. Taruhlah sebuah contoh dalam konteks dakwah misalnya, ketika yang menjadi pendakwah dalam media massa adalah mereka yang secara tampilan menarik, dan sedikit mengabaikan keilmuaannya, yang penting bisa senyum, tertawa, akting, ataupun ngelawak. Nah, ketika penekanannya hanya kepada tampilan semata, bisa jadi kesempatan inilah yang dimanfaatkan oleh segelintir orang untuk mencari popularitas.

\footnotetext{
${ }^{24}$ Moch. Fahrurozi, Dakwah Islam Dan Inovasi Media: Peluang Dan Ancaman Media Global Atas Dakwah Islam, Komunika: Jurnal Dakwah dan Komunikasi Vol.4 No.1 Januari-Juni 2010 pp.121-129. ISSN: 1978-1261

${ }^{25}$ Moch. Fahrurozi, Dakwah Islam Dan Inovasi Media: Peluang Dan Ancaman Media Global Atas Dakwah Islam, Komunika: Jurnal Dakwah dan Komunikasi Vol.4 No.1 Januari-Juni 2010 pp.121-129. ISSN: 1978-1261.

${ }^{26}$ Dalam sejarah Kristiani, seperti dikutip oleh Abdullah Sattar dari bukunya Komarudin Hidayat "Kegagalan Peran Sosial Agama" dalam Revitalisasi Islam, bahwasanya para teolog agama Kristen dan Bapak gereja di Barat pernah memperoleh serangan yang amat keras dari para filsuf dan ilmuan ketika mereka mengatakan bahwa agama telah usang. Menurut mereka ajaran agama tidak lebih dari sebuah ilusi dan hiburan sesaat untuk lari dari derita hidup, tetapi tidak mampu menyelesaikan problema hidup itu sendiri. Dalam pandangn mereka, agama yang tampil dalam bentuk ajaran lembaga gereja lebih sibuk membicarakan tuhan dan konsep keselamatan di tengah derita manusia, tetapi tidak menyentuh sama sekali dan tidak menyelesaikan derita yang riil yang dirasakan manusia. Kegiatan agama tak lebih dari ritual khutbah memuji dan membela tuhan, namun tidak memiliki konsep untuk melakukan pembelaan kepada mereka yang tertindas secara ekonomi dan politik. Lihat, Abdullah Sattar, Komodifikasi Agama Dalam Televisi, Jurnal Penelitian Vol. 18 No. 2 Tahun 2013

${ }^{27}$ Azyumardi Azra, Komodifikasi Islam...
} 
Untuk mengantisipasi hal itu, menarik sebenarnya apa yang ditawarkan oleh Jalaluludin Rahmat, paling tidak untuk memberi gelar kyai atau ustaz harus dengan persyaratan, misalnya punya pesantren, punya jamaah yang khusus dibina, memiliki pengetahuan yang mendalam tentang agama. Artinya, harus ada rambu-rambu yang jelas bagi media massa agar menjadi rujukan dalam merekrut layak dan tidaknya untuk dijadikan pendakwah di media massa. Hal ini juga menjadi langkah antisipasi, supaya pendakwah media massa yang hanya bermodalkan penampilan tanpa ditopang dengan pengetahuan agama yang mumpuni, tidak menjadi aib dikemudian hari, baik bagi media, maupun aktivitas dakwah itu sendiri

\section{Penutup}

Komodifikasi sejatinya tidak bisa dipisahkan dari kapitalisme. Dari rahimnya lahir sebuah praktek dagang yang tidak lagi peduli pada urgensi dari barang yang dijual, asalkan bisa menjadi uang, maka dalam kaca mata komodifikasi, semuanya adalah halal.

Komodifikasi agama, termasuk dakwah, juga adalah korban dari praktek kapitalisme tadi. Akarnya adalah hadirnya media-media di tengah masyarakat yang berlomba-lomba menayangkan tontonan agama sebagai bagian yang tak terpisahkan dari program-program yang diproduksi. Sedangkan media bukanlah lembaga yang tanpa pamrih. Mereka juga butuh biaya bahkan keuntungan dari program-program dakwah yang diproduksi, karena konsep kapitalisme.

Namun demikian, kondisi semacam ini tidak perlu dikhawatirkan dalam artian harus tetap dimonitoring secara intens. Karena bagaimanapun, dengan hadirnya dakwah melalui media massa, dakwah Islam dalam konteks masyarakat modern justru lebih segmented dengan memilih media-media tertentu untuk masyarakat-masyarakat dengan tipe-tipe dan karakter tertentu.Oleh karena itu, dibutuhkan berbagai pendekatan dengan media-media baru untuk mengekalkan aktivitas dakwah sebagai proses yang menginformasikan pesan-pesan keagamaan dan bukan hanya sekedar sarana untuk mendapatkan keuntungan dari praktik komodifikasi media tadi.

\section{DAFTAR PUSTAKA}

Abdullah, Irwan. 2007. Konstruksi dan Reproduksi Kebudayaan, Yogyakarta: Pustaka Pelajar.

Arief, Yovantra \& Prasetyo, Wisnu Utomo, Orde Media: Kajian Televisi dan Media di Indonesia, (Yogyakarta: INSIST Press, 2015)

Aripudin, Acep. 2013. Sosiologi Dakwah, Bandung: PT Remaja Rosdakarya.

Haryanto, Sindung. Spektrum Teori Sosial dari Klasik Hingga Modern,(Jakarta: Ar-Ruzz Media, 2012)

Hidayat, Komarudin, 2001. Kegagalan Peran Sosial Agama", Dalam Revitalisasi Islam, Yogyakarta: Pustaka Pelajar.

K. Stephen, Sanderson. 2003. Makro Sosiologi, Sebuah Pendekatan terhadap Reaitas Sosial (terjemahan), Jakarta: Raja Grafindo Persada.

Subandi,Idi Ibrahim. 2007. Budaya Populer Sebagai Komunikasi: Dinamika Popscape dan Mediascape di Indonesia Kontemporer, Yogyakarta: Jalasutra.

Sugihartati, Rahma. 2014. Perkembangan Masyarakat Informasi \& Teori Sosial Kontemporer, Jakarta: Kencana Prenada Mediaa Group.

Sulaiman, Munandar. Ilmu Sosial Dasar: Teori dan Konsep Ilmu Sosial, (Bandung: PT Rfika Aditama, 2015)

Zafrulkhan, 2012. Filsafat Umum: Sebuah Pendekatan Tematik, Jakarta: PT Raja Grafindo Persada. 


\section{Jurnal \& Media Online:}

Abdullah Sattar, Komodifikasi Agama Dalam Televisi, Jurnal Penelitian Vol. 18 No. 2 Tahun 2013

Moch. Fahrurozi, Dakwah Islam Dan Inovasi Media: Peluang Dan Ancaman Media Global Atas Dakwah Islam, Komunika: Jurnal Dakwah dan Komunikasi Vol.4 No.1 Januari-Juni 2010 pp.121-129. ISSN: 1978-1261

---------Privatisasi Agama: Globalisasi dan Komodifikasi Agama, Komunika:Jurnal Dakwah dan Komunikasi Vol.8 No.1 Januari-Juni 2012

Fitri Murfianti, Komodifikasi Dakwah Dalam Religiotainment Di Stasiun Televisi Indonesia Jurnal.ISI-Volume 3 no. 1 Juni 2012

Azyumardi Azra, Komodifikasi Islam, Koran Republika Edisi 11 September 2008. Versi yang sama mengenai pembahasan terkait Komodifikasi Islam, juga bisa di akses pada website UIN Syarif Hidayatullah Jakarta (www. uinjkt. ac.id).

Afif Fusalhan, Kavitalisme Media Dan Komodifikasi Agama: Pesan di Balik Cerita Sinetron Religi Pesantren Rock n Roll Season 3, Skripsi Jurusan Komunikasi Penyiaran Islam, Fakultas Dakwah, (Universitas Negeri Sunan Kalijaga 2014).

Moch. Khairul Arif, Kuliah Filsafat Dakwah, 08 Desember 2014 